\title{
Hong Kong Society of Clinical Blood Management recommendations for implementation of patient blood management
}

\author{
YF Chow *, Benny CP Cheng, HK Cheng, Betty Ho, CK Lee, SK Ng, Rita So, KC Tse, Cindy Tsui, \\ Ryan Wan, Steven Wong, for the Hong Kong Society of Clinical Blood Management Limited
}

\section{A B S T R A C T}

Patient blood management (PBM) is a patientcentred, multidisciplinary approach to optimise red cell mass, minimise blood loss, and manage tolerance to anaemia in an effort to improve patient outcomes. Well-implemented PBM improves patient outcomes and reduces demand for blood products. The multidisciplinary approach of PBM can often allow patients to avoid blood transfusions, which are associated with less favourable clinical outcomes. In Hong Kong, there has been increasing demand for blood in the ageing population, and there are simultaneous blood safety and donor issues that are adversely affecting the blood supply. To address these challenges, the Hong Kong Society of Clinical Blood Management recommends implementation of a PBM programme in Hong Kong, including strategies such as optimising red blood cell mass, improving anaemia management, minimising blood loss, and rationalising the use of blood and blood products.
Hong Kong Med J 2020;26:331-8

https://doi.org/10.12809/hkmj208397

${ }^{1}$ YF Chow *, FHKAM (Anaesthesiology)

${ }^{2}$ BCP Cheng, FHKAM (Anaesthesiology)

${ }^{3}$ HK Cheng, FHKAM (Anaesthesiology)

${ }^{4}$ B Ho, FHKAM (Anaesthesiology)

${ }^{5}$ CK Lee, FHKAM (Medicine)

${ }^{6} \mathrm{SK}$ Ng, FHKAM (Anaesthesiology)

${ }^{7}$ R So, FHKAM (Anaesthesiology)

${ }^{3}$ KC Tse, FHKAM (Anaesthesiology)

${ }^{8}$ C Tsui, FHKAM (Anaesthesiology)

${ }^{6}$ R Wan, FHKAM (Anaesthesiology)

${ }^{1} \mathrm{~S}$ Wong, FHKAM (Anaesthesiology)

1 Department of Anaesthesiology and OT Services, Queen Elizabeth Hospital, Hong Kong

2 Department of Anaesthesia and Operating Theatre Services, Tuen Mun Hospital, Hong Kong

Department of Anaesthesia and Operating Theatre Services, Tseung Kwan O Hospital, Hong Kong

${ }^{4}$ Department of Anaesthesiology, Pamela Youde Nethersole Eastern Hospital, Hong Kong

${ }^{5}$ Hong Kong Red Cross Blood Transfusion Service, Hong Kong

${ }^{6}$ Private Practice, Hong Kong

7 Department of Anaesthesia, Princess Margaret Hospital, Hong Kong

${ }^{8}$ Department of Anaesthesia and Intensive Care, Prince of Wales Hospital, Hong Kong

* Corresponding author: yfchowhk@yahoo.com.hk

\section{Introduction}

Clinical blood transfusion remains an essential and irreplaceable part of modern medicine, either as an independent therapeutic modality or an additional support to other clinical therapies. Anaemia, a serious disease with a worldwide burden on both hospitalised patients and society, ${ }^{1-3}$ is often managed with blood transfusion as part of the treatment. Without a reliable substitute, sourcing of the blood used in transfusion relies solely on donations from voluntary, non-remunerated blood donors. Because blood is a biological substance, it is impossible to completely eliminate adverse outcomes during and after transfusion. Worldwide, particularly in developed countries, the ageing of the population and emerging infectious diseases are the two most important and ongoing threats to the sustainability of the safe blood supply. Ageing populations tend to have increased numbers of complex surgeries and cancer treatments requiring increased blood transfusions. ${ }^{4}$ In 2016, the mean per capital blood use in high-income countries was 32 units of red cell components per 1000 population. Moreover, the most frequently transfused patient group is aged $>60$ years, accounting for up to $79 \%$ among these transfusions. ${ }^{5}$ Infectious pathogens continue to emerge rapidly, which could adversely affect transfusion safety both directly (if the pathogen is transmitted through blood transfusion) and indirectly (if outbreaks reduce the pool of available donors). ${ }^{6}$ Recent examples include the Zika virus outbreak in South America and the dengue, hepatitis E, and chikungunya virus outbreaks in Southeast Asia. ${ }^{7}$ Therefore, maintenance of a sustainable and safe blood supply continues to be a challenging task that requires a substantial amount of effort and resources.

There is evidence associating blood transfusion with less favourable clinical outcomes. ${ }^{8,9}$ This evidence includes a higher incidence of recurrence in cancer surgeries, higher operative mortality, failure to rescue from sepsis, and other 


\section{香港臨床血液管理學會有關實施患者血液管理 的建議}

\section{周雨發、鄭振邦、鄭鴻佳、何碧頣、李卓廣、吳兆強、 \\ 蘇靜儀、謝健忠、徐倩荵、温卓進、黃河山、 香港臨床血液管理學會有限公司}

患者血液管理（PBM）是一種以患者為中心的多學科方法, 可優化 紅細胞質量、把失血量減至最低並管理對貧血的耐受性, 以改善患者 治療效果。只要推行得宜, PBM可提升醫療成效並減少對血液製成品 的需求。PBM的多學科方法可使患者避免輸血, 這與臨床效果較差有 關。在香港, 人口老化使血液需求不斷增加, 同時存在血液安全和供 血者問題, 對血液供應產生不利影響。為了應對這些挑戰, 香港臨床 血液管理學會建議在香港實施PBM計劃, 包括優化紅細胞質量、改善 貧血管理、減少失血以及合理使用血液和血液製成品等策略。 serious complications like renal, neurological, cardiac, and pulmonary dysfunction. ${ }^{10}$ Patient blood management (PBM) is a patient-centred and multidisciplinary framework that has been rapidly developing throughout the last decade in Western countries to improve the treatment outcomes of patients who may need blood transfusions during their treatment. It refers to evidence-based medical and surgical concepts designed to improve patient outcomes. Commonly, PBM employs a threepillar approach: (1) optimise red blood cell mass; (2) minimise blood loss; and (3) manage anaemia (Table $1^{11-14}$ ). Indeed, PBM optimises the patient's condition before, during, and after the procedure and only recommends transfusion when indicated. It directly addresses the triad of independent risk factors that can affect patient outcomes: anaemia, blood loss, and transfusion. Anaemia is appropriately and timely managed according to its aetiology instead of being bluntly corrected by blood transfusion. Thereby, blood loss is minimised, and the harm associated with inappropriate transfusions is avoided. ${ }^{15}$ Therefore, countries that have implemented PBM have shown improvement of patients' outcomes, such as overall survival, disease recurrence, infection rate, length of stay in intensive care unit and hospital, cost, and blood utilisation. ${ }^{16-22}$ During the Sixty-third World Health Assembly in 2010, member states were urged to establish or strengthen systems for the safe and rational use of blood products and to provide training for all staff involved in clinical transfusion, to implement potential solutions to minimise transfusion errors and promote patient safety, and to promote the availability of transfusion alternatives including, where appropriate, autologous transfusion and PBM. $^{23}$

TABLE I. Three pillars of patient blood management (adapted and modified) ${ }^{11-14}$

\begin{tabular}{|c|c|c|c|}
\hline & $\begin{array}{l}\text { Pillar one: } \\
\text { Optimise red blood cell mass }\end{array}$ & $\begin{array}{l}\text { Pillar two: } \\
\text { Minimise blood loss }\end{array}$ & $\begin{array}{l}\text { Pillar three: } \\
\text { Manage anaemia }\end{array}$ \\
\hline Preoperative & $\begin{array}{l}\text { Detect/treat anaemia and iron deficiency } \\
\text { Treat underlying causes } \\
\text { Optimise haemoglobin } \\
\text { Cease medications }\end{array}$ & $\begin{array}{l}\text { Identify, manage, and treat bleeding/ } \\
\text { bleeding risk } \\
\text { Minimise phlebotomy } \\
\text { Plan/rehearse procedure }\end{array}$ & $\begin{array}{l}\text { Assess patients' bleeding history and } \\
\text { develop management plan } \\
\text { Estimate patients' tolerance for blood loss } \\
\text { Optimise cardiopulmonary function }\end{array}$ \\
\hline Intra-operative & $\begin{array}{l}\text { Time surgery with optimisation of } \\
\text { erythropoiesis and red blood cell mass }\end{array}$ & $\begin{array}{l}\text { Meticulous haemostatic/surgical/ } \\
\text { anaesthetic techniques } \\
\text { Cell salvage techniques } \\
\text { Avoid coagulopathy } \\
\text { Patient positioning/warming } \\
\text { Pharmacological agents }\end{array}$ & $\begin{array}{l}\text { Optimise cardiopulmonary function } \\
\text { Optimise ventilation and oxygenation } \\
\text { Restrictive transfusion strategies }\end{array}$ \\
\hline Postoperative & $\begin{array}{l}\text { Manage anaemia and iron deficiency } \\
\text { Manage medications and potential } \\
\text { interactions }\end{array}$ & $\begin{array}{l}\text { Monitor and manage postoperative } \\
\text { bleeding } \\
\text { Keep patient warm } \\
\text { Minimise phlebotomy } \\
\text { Awareness of drug interactions and } \\
\text { adverse events } \\
\text { Treat infections promptly }\end{array}$ & $\begin{array}{l}\text { Maximise oxygen delivery } \\
\text { Minimise oxygen use } \\
\text { Treat infections promptly } \\
\text { Tolerance of anaemia } \\
\text { Restrictive transfusion strategies }\end{array}$ \\
\hline
\end{tabular}




\section{Blood supply and transfusion demand in Hong Kong}

Although Hong Kong has a long history of selfsufficiency in terms of blood supply, population ageing has brought a significant increase in demand for blood over the last decade..$^{24}$ Since 2015, the Hong Kong Blood Transfusion Service has experienced excessive difficulties at mobilising citizens to maintain a stable, safe blood supply. As a result, the Blood Transfusion Service faces a number of blood safety and donor issues that affect the blood supply. Emerging infectious diseases like Zika virus and low pre-donation haemoglobin due to iron deficiency are typical examples that may prevent apparently healthy persons from donating blood.

As blood is irreplaceable and has a limited shelf life, securing a sustainable and safe blood supply is of paramount importance in the modern healthcare system to ensure that patients' transfusion needs are met promptly and appropriately. Strategies to enhance new donor recruitment and existing donor retention should be undertaken by the Blood Transfusion Service to increase the blood supply. However, demand control measures should be simultaneously implemented to reduce the pressure on the supply side. In Hong Kong, there has been increasing awareness of the concept of PBM beginning in the past 2 years, and small-scale projects have been initiated. One local project was able to increase the preoperative haemoglobin concentration and reduce the transfusion rate after implementation of PBM. ${ }^{25}$ In the UK, the National Institute for Health and Care Excellence recommended consideration of single-unit transfusions for adults without active bleeding in November $2015 .{ }^{26}$ On the basis of this recommendation, some medical departments in Hong Kong have implemented single-unit blood transfusions over the past 2 years, and unpublished audit results demonstrate an overall reduction of red blood cell transfusions in general medical in-patients over that period.

With the objective of improving patients' outcomes and better managing transfusion demand, a group of experienced clinicians from different specialties and hospitals in Hong Kong has established the Hong Kong Society of Clinical Blood Management to continuously promote PBM in Hong Kong. The Society aims to discuss and make recommendations regarding the implementation of PBM in Hong Kong. Below are three areas of focus that the Society intends to address.

\section{Optimising patients' red blood cell mass and better managing anaemia}

Anaemia is a serious disease burden in both hospitalised patients and society. ${ }^{1-3}$ Haematopoiesis and anaemia management are important modifiable risk factors for adverse outcomes. ${ }^{9,27,28}$ Beneficial outcomes in this important pillar of PBM are seen in not only surgical patients but also other patient groups, such as those with underlying medical, obstetric, or gynaecological problems. Therefore, clinical guidelines have recommended that anaemia be promptly recognised and the underlying causes identified and managed appropriately. ${ }^{29}$ Because some surgical patients have an increased risk of bleeding, haemoglobin measurement well before operation in all patients could provide adequate time to manage any anaemia before surgery and improve outcomes. ${ }^{29}$

Red blood cell transfusion should be restricted to the minimal amount necessary to achieve clinical stability and to patients presenting with severe iron deficiency anaemia and alarming symptoms (eg, haemodynamic instability) and/or risk criteria (eg, coronary heart disease). ${ }^{30,31}$ As iron deficiency (whether absolute or functional) is commonly found in anaemic patients, its correction should be promptly instituted. Oral iron supplements, provided as ferrous or ferric salts, are usually the first line of treatment for uncomplicated iron deficiency anaemia because of their availability, ease of administration, and relatively low cost. However, because of these supplements' notorious gastrointestinal adverse effects, intravenous iron should be considered in patients with intolerance to oral iron and when more rapid restoration of the iron store is expected. 'Newer' intravenous iron formulations with safer profiles, such as ferric carboxymaltose or iron isomaltoside, which allow for a short-time (15-60 min) infusion of high iron doses $(\geq 1000 \mathrm{mg})$, are now available for use in both in-patients and out-patients. Such intravenous iron formulations can rapidly correct iron deficiency and anaemia within a few weeks (vs the few months needed for correction via oral iron). At the University Hospitals Plymouth, UK, intravenous iron is given to successfully treat iron deficiency anaemia when surgery with anticipated blood loss of $>500 \mathrm{~mL}$ is anticipated within 6 weeks. ${ }^{32}$ As a result, intravenous iron has become an important component of PBM management strategies.

In Hong Kong, the Blood Transfusion Service and the Hong Kong Medical Association have recently issued a simple algorithm to aid general practitioners with early and prompt recognition of anaemia and its management. ${ }^{33}$ Further work is required to enhance the general population's awareness of anaemia and iron deficiency issues, their diagnosis, and improving their management.

\section{Minimising blood loss}

Reducing or minimising blood loss in hospitalised patients is another approach to reduce the need for 
blood transfusion and improve patients' outcomes. Some might consider that this type of planning should only occur in surgical or operative settings, but reducing iatrogenic blood loss in non-operative settings has also been shown to improve patients' outcomes. Table $2^{34-43}$ highlights the measures that have been shown to be effective at minimising blood loss. These measures are safe and have not affected organ function or caused other complications. Instead, they reduce iatrogenic blood loss and avoid blood transfusions.

Temporary cessation of antiplatelet and anticoagulant medications in the perioperative period may lead to reduced blood loss and transfusion requirements if the risks of perioperative thromboembolic events and bleeding are balanced. Meticulous surgical techniques such as performing minimally invasive surgery, judicious use of electrocautery, tourniquets, topical haemostatic agents, and intra-operative blood salvage can minimise surgery-related blood loss. ${ }^{44-49}$

A number of anaesthetic techniques can also help to reduce blood loss. Permissive hypotension refers to the lowering of mean arterial pressure to values between 50 and $65 \mathrm{~mm} \mathrm{Hg}$ with the goal of reducing blood flow to the surgical field, thereby reducing blood loss and improving visibility in the surgical field. ${ }^{50}$ Studies have shown that permissive hypotension during anaesthesia reduced blood loss in spinal surgery, radical prostatectomy, functional endoscopic sinus surgery, and orthopaedic surgery. ${ }^{51-53}$ It can also reduce blood loss and blood product utilisation in adult trauma patients with haemorrhagic shock. ${ }^{54}$ Organ hypoperfusion is the major drawback, and therefore, this strategy may not be suitable for patients with coronary artery disease, cerebrovascular disease, traumatic brain injury, or spinal injury.

Prevention of perioperative hypothermia is another strategy that can help to reduce blood loss. Hypothermia is defined as a core temperature $<36^{\circ} \mathrm{C}$ and is a common consequence of anaesthesia. ${ }^{55}$ Even mild hypothermia, defined as a core temperature between $35^{\circ} \mathrm{C}$ and $36^{\circ} \mathrm{C}$, significantly increases perioperative blood loss and augments the transfusion requirement. ${ }^{56}$ Therefore, measures should be taken to prevent inadvertent hypothermia, including identification of high-risk patients, prewarming before surgery, intra-operative monitoring of body temperature, using warm intravenous/ irrigation fluid and forced-air warming devices, and avoidance of unnecessary body exposure. ${ }^{57}$

Another method to minimise blood loss is acute normovolaemic haemodilution. Acute normovolaemic haemodilution involves withdrawal of whole blood with concurrent infusion of fluids to maintain normovolaemia. ${ }^{58}$ The autologous blood is re-infused at the conclusion of the surgery. This method has been shown to significantly reduce the incidence and volume of allogeneic blood transfusion, and its use should be considered in adult patients who undergo surgery in which substantial blood loss is anticipated. ${ }^{4}$ However, relatively profound anaemia is expected during the surgery, which may induce tissue ischaemia, particularly in the myocardium. ${ }^{45}$ Furthermore, the effects of normovolaemic haemodilution on morbidity and mortality are uncertain.

Appropriate patient positioning during the intra-operative period may also help to reduce surgery-related blood loss. Elevation of the surgical site above the right atrium facilitates venous return and reduces venous engorgement. For example, the reverse Trendelenburg position has been shown to reduce intra-operative blood loss in endoscopic sinus surgery. ${ }^{46}$

Using the wide pad support widths of the Wilson frame, when compared with narrow pad support widths, significantly decreased intra-abdominal pressure and intra-operative blood loss in patients undergoing spine surgery in the prone position. ${ }^{47}$ Pharmacological agents can also be used to facilitate haemostasis. Tranexamic acid has been studied extensively in a wide range of surgeries and has been shown to reduce blood loss effectively without increasing the risk of thromboembolic events. ${ }^{48,49}$ In

TABLE 2. Measures to minimise blood loss in both operative and non-operative settings ${ }^{34-43}$

\begin{tabular}{ll}
\hline Surgical/operative settings & \multicolumn{1}{c}{ Non-operative settings } \\
\hline $\begin{array}{l}\text { 1. Early management of bleeding risk, such as cessation or alteration } \\
\text { of antiplatelet or anticoagulation therapy }\end{array}$ & $\begin{array}{l}\text { Strategies to minimise the blood volume taken and thereby reduce } \\
\text { iatrogenic blood loss, eg, },^{34-37}\end{array}$ \\
$\begin{array}{ll}\text { 2. Anaesthetic techniques to minimise blood loss or the use of } & \text { - Small-volume phlebotomy tubes } \\
\text { allogeneic blood, eg, }{ }^{38} & \text { Closed inline sampling devices } \\
\text { - Avoidance of hypothermia (core temperature }<36^{\circ} \mathrm{C} \text { ) } & \text { Frequent evaluation of routine blood sampling orders and cumulative } \\
\text { - Permissive hypotension (mean arterial pressure } 50-65 \mathrm{~mm} \mathrm{Hg}) & \text { - Bundled scheduling of blood sampling } \\
\text { - Autologous blood pre-deposit } & \text { - Use of non-invasive techniques and measurements, such as } \\
\text { - Acute normovolaemic haemodilution }{ }^{39,40} & \text { continuous non-invasive haemoglobin monitoring } \\
\text { - Intra- and post-operative cell salvage } & \\
\text { 3. Guided transfusion therapy through the use of point of care testing } & \\
\text { 4. Use of antifibrinolytics }{ }^{41-43} & \end{array}$ \\
\hline
\end{tabular}


case of significant haemorrhage that is refractory to standard treatment, the use of recombinant factor VIIa should also be considered. ${ }^{59}$

Diagnostic phlebotomy for laboratory testing can also be a significant source of blood loss, especially in critically ill patients. ${ }^{60}$ Such blood loss has been associated with the development of anaemia and the need for transfusion. ${ }^{61}$ Therefore, blood tests should be ordered only when necessary, and the volume of blood collected should be the minimum required. Paediatric bottles can be used to minimise the blood volume collected for testing, which in turn reduces iatrogenic blood loss and transfusion requirements. ${ }^{60}$ Point-of-care testing devices require smaller blood volumes for analysis and serve as an alternative to traditional laboratory testing. Blood sampling from arterial and central venous lines traditionally involves discarding the initial blood sample. The method of returning the initial blood sample back to the patients has been used to significantly reduce iatrogenic blood loss, ${ }^{62}$ and this measure should be considered.

\section{Rationalising use of blood and blood components}

As blood transfusion is not without risks, consideration should be given to the balance of benefits against risks. Most would advocate the adoption of a quality clinical transfusion process, ie, "transfusion of the right number of units of blood to the right patient at the right time, in the right conditions, and according to appropriate guidelines".63 Thus, clinicians should proceed through a chain of related events by making appropriate decisions (Fig).

\section{Recommendations for implementation of patient blood management in Hong Kong}

On the basis of the above three areas for consideration, as well as advice from the Joint United Kingdom (UK) Blood Transfusion and Tissue Transplantation Services Professional Advisory Committee ${ }^{64}$ and the World Health Organization, ${ }^{65}$ the Hong Kong Society of Clinical Blood Management makes the following recommendations:

1. A PBM framework, covering primary, hospital, research, audit, and public health measures, should be developed for use in Hong Kong after engagement of different stakeholders;

2. Healthcare professionals, patients, and the public should be educated on the appropriateness of blood transfusion, and PBM programmes; and

3. A PBM framework should be developed for application in Hong Kong, including early recognition and better management of anaemia and iron deficiency in patients and the general population; optimisation of patients'

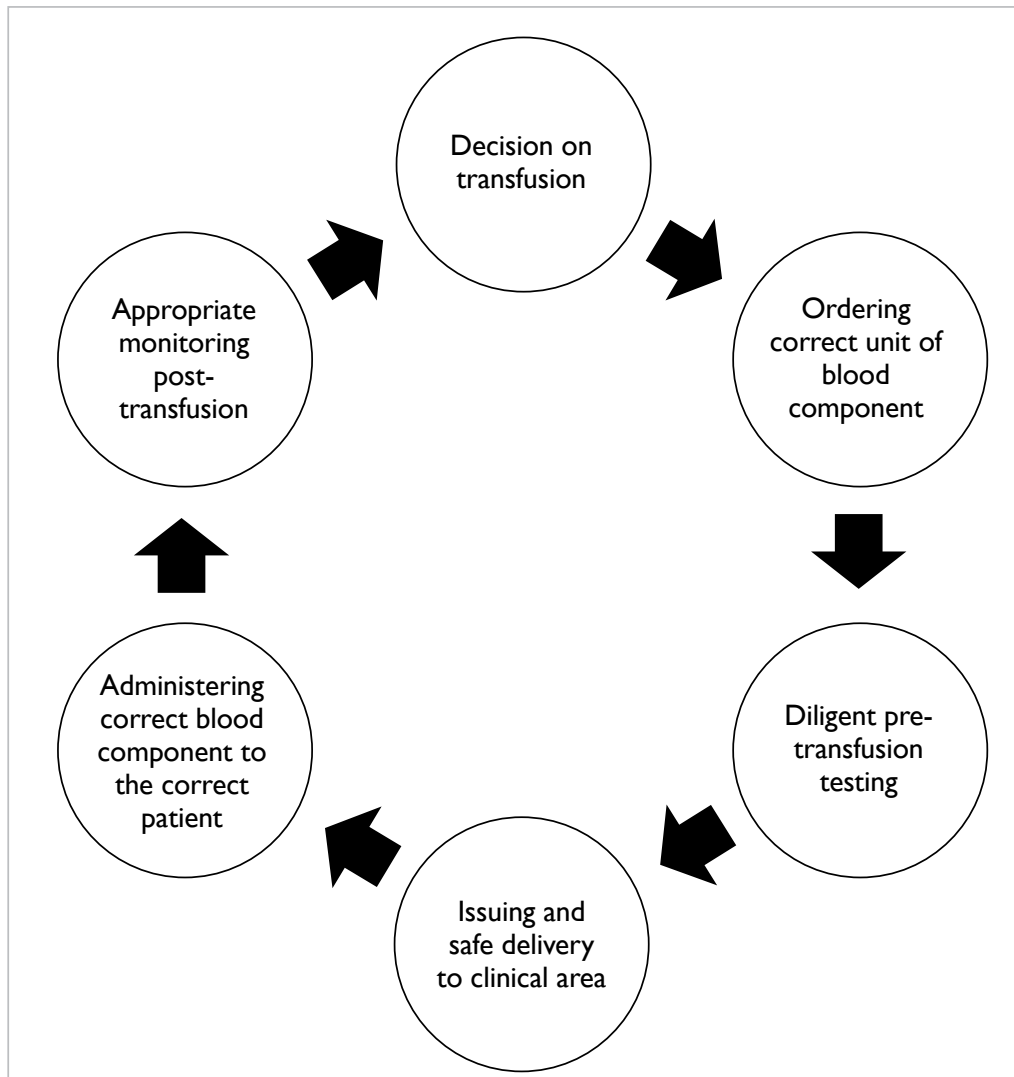

FIG. Key decision-making points in clinical blood transfusion

haematopoiesis and correction of coagulation before surgical procedures; and application of various blood-saving technologies/techniques and point-of-care testing to optimise patients' outcomes with less transfusion.

The proposed PBM framework is a multipronged approach that encompasses a wide range of sectors, disciplines, specialties, and departments. Its implementation will include hospitals, clinics, healthcare facilities, and public health measures to provide care to in-patients, out-patients, and the public of Hong Kong. However, a number of barriers exist that may hamper PBM implementation in Hong Kong. ${ }^{66,67}$ These include misconceptions related to blood transfusion and difficulties accessing contemporary evidence and data about PBM. There are also existing cultural pressures to retain the status quo, with inadequate incentive for change, as blood is currently delivered freely and efficiently to receivers in Hong Kong. Resources may be inadequate or unequally allocated, such as ferritin assays and intravenous iron preparations for early diagnosis and effective treatment of anaemia, or cell savers and active patient warming equipment for minimising blood loss and conserving blood during surgery. Logistical complexities such as timely investigation and treatment of preoperative anaemia before 
elective surgery and establishment of point-of-care testing coagulation management programmes may also present obstacles. Finally, PBM lacks specific established quality mechanisms, such as associated policies, standards, guidelines, documentation, performance indicators, coordination, monitoring, evaluation, and feedback.

To overcome these barriers, strong leadership with central steering and empowerment of PBM advocates is required to reinforce and coordinate the current piecemeal and uncoordinated efforts of PBM promotion. The goal of PBM is not simply to reduce the amount of blood transfusion. It is a continuing programme of quality improvement that has the goal of improving patient outcomes via its different measures. With reference to other countries' experiences and the barriers and challenges that could limit the implementation of PBM in clinical practice, an appropriate framework with local interest should be developed to implement PBM practices at the hospital and territory level. ${ }^{11,68,69}$

\section{Conclusion}

On the basis of the scientific evidence on the successful implementation of PBM and its improvement of patient outcomes, the Hong Kong Society of Clinical Blood Management strongly recommends that Hong Kong implement PBM as soon as possible. The Society will continue to work with relevant professional bodies, patients, and stakeholders to facilitate the local implementation of PBM.

\section{Author contributions}

All authors contributed to the concept or design of the study, acquisition and analysis or interpretation of data, drafting of the manuscript, and critical revision of the manuscript for important intellectual content. All authors had full access to the data, contributed to the study, approved the final version for publication, and take responsibility for its accuracy and integrity.

\section{Conflicts of interest}

All authors have disclosed no conflicts of interest.

\section{Funding/support}

This study received no specific grant from any funding agency in the public, commercial, or not-for-profit sectors.

\section{References}

1. GBD 2016 Disease and Injury Incidence and Prevalence Collaborators. Global, regional, and national incidence, prevalence, and years lived with disability for 328 diseases and injuries for 195 countries, 1990-2016: a systematic analysis for the Global Burden of Disease Study 2016. Lancet 2017;390:1211-59.

2. Kassebaum NJ, Jasrasaria R, Naghavi M, et al. A systematic analysis of global anemia burden from 1990 to 2010. Blood
2014;123:615-24

3. Kulier A, Gombotz H. Perioperative Anemia [in German]. Anaesthesist 2001;50:73-86.

4. Williamson LM, Devine DV. Challenges in the management of the blood supply. Lancet 2013;381:1866-75.

5. Global Status Report on Blood Safety and Availability. World Health Organization; 2017.

6. Marks PW, Epstein JS, Borio LL. Maintaining a safe blood supply in an era of emerging pathogens. J Infect Dis 2016;213:1676-7.

7. Faddy HM, Viennet E, Flower RL. Transfusion risk from emerging pathogens in the Asia-Pacific region. ISBT Science Series 2016;11:143-8.

8. Hans G, Zacharowski K, Spahn DR. Patient blood management. 2016. Available from: http://www.thiemeconnect.de/products/ebooks/lookinside/10.1055 /b-0036-129702. Accessed 15 Nov 2019.

9. Musallam KM, Tamim HM, Richards $\mathrm{T}$, et al. Preoperative anaemia and postoperative outcomes in non-cardiac surgery: a retrospective cohort study. Lancet 2011;378:1396-407.

10. Ferraris VA, Hochstetler M, Martin JT, Mahan A, Saha SP. Blood transfusion and adverse surgical outcomes: the good and the bad. Surgery 2015;158:608-17.

11. Australia National Blood Authority. Patient blood management. Available from: https://www.blood.gov.au/ patient-blood-management-pbm. Accessed 8 Mar 2019.

12. Isbister JP. The three-pillar matrix of patient blood management-an overview. Best Pract Res Clin Anaesthesiol 2013;27:69-84.

13. Spahn DR, Goodnough LT. Alternatives to blood transfusion. Lancet 2013;381:1855-65.

14. Hofmann A, Farmer S, Towler SC. Strategies to preempt and reduce the use of blood products: an Australian perspective. Curr Opin Anaesthesiol 2012;25:66-73.

15. Frietsch T, Shander A, Faraoni D, Hardy JF. Patient blood management is not about blood transfusion: it is about patients' outcomes. Blood Transfus 2019;17:331-3.

16. Morden Healthcare. Hospitals see improved outcomes, lower costs as blood transfusions drop. 2017. Available from: http://www.modernhealthcare.com/article/20170721/ NEWS/170729977. Accessed 15 Nov 2019.

17. Althoff FC, Neb H, Herrmann E, et al. Multimodal patient blood management program based on a three-pillar strategy: a systematic review and meta-analysis. Ann Surg 2019;269:794-804.

18. Leahy MF, Hofmann A, Towler S, et al. Improved outcomes and reduced costs associated with a health-system-wide patient blood management program: a retrospective observational study in four major adult tertiary-care hospitals. Transfusion 2017;57:1347-58.

19. Muñoz M, Acheson AG, Auerbach M, et al. International consensus statement on the peri-operative management of anaemia and iron deficiency. Anaesthesia 2017;72:233-47.

20. Shander A, Van Aken H, Colomina MJ, et al. Patient blood management in Europe. Br J Anaesth 2012;109:55-68.

21. Vaglio S, Gentili S, Marano G, et al. The Italian regulatory guidelines for the implementation of patient blood management. Blood Transfus 2017;15:325-8.

22. Vaglio S, Prisco D, Biancofiore G, et al. Recommendations for the implementation of a patient blood management programme. Application to elective major orthopaedic surgery in adults. Blood Transfus 2016;14:23-65. 
23. World Health Organization. Sixty-third World Health Assembly: availability, safety and quality of blood products. 21 May 2010. Available from: http://apps.who.int/gb/ ebwha/pdf_files/wha63/a63_r12-en.pdf. Accessed 8 Mar 2019.

24. Hong Kong Red Cross Blood Transfusion Service. Fact sheet of blood collection and use. Available from: https:// www5.ha.org.hk/rcbts/fs2016?lang=en. Accessed 29 Feb 2020.

25. Fong CM. Hospital Authority Convention 2019 masterclass 1.4 patient blood management: experience from Tseung Kwan O Hospital. 2019. Available from: https://dryfta-assets.s3.eu-central-1.amazonaws.com/ assets/haconvention2019/editorimages/1562116855M1.4 PatientBloodManagementv.2.pdf. Accessed 29 Feb 2020.

26. National Institute for Health and Care Excellence. Blood transfusion. NICE guideline 24. 2015. Available from: https://www.nice.org.uk/guidance/ng24. Accessed $20 \mathrm{Apr}$ 2020.

27. Fowler AJ, Ahmad T, Phull MK, Allard S, Gillies MA, Pearse RM. Meta- analysis of the association between preoperative anaemia and mortality after surgery. Br J Surg 2015;102:1314-24

28. Mueller MM, Van Remoortel H, Meybohm P, et al. Patient blood management: recommendations from the 2018 Frankfurt Consensus Conference. JAMA 2019;321:983-97.

29. De Hert S, Staender S, Fritsch G, et al. Pre-operative evaluation of adults undergoing elective noncardiac surgery: updated guideline from the European Society of Anaesthesiology. Eur J Anaesthesiol 2018;35:407-65.

30. Carson JL, Guyatt G, Heddle NM, et al. Clinical practice guidelines from the AABB: red blood cell transfusion thresholds and storage. JAMA 2016;316:2025-35.

31. Franchini M, Marano G, Mengoli C, et al. Red blood cell transfusion policy: a critical literature review. Blood Transfus 2017;15:307-17.

32. Cleland SR, Thomas W. Iron homeostasis and perioperative management of iron deficiency. BJA Education 2019;19:390-7.

33. Lau CW, Lee CK. A practical guide of anaemia management for general practitioners. HKMA CME Bulletin July 2018: 2-9.

34. Australia Victoria State Government. Reducing iatrogenic blood loss-clinical practice guideline template. Available from: https://www2.health.vic.gov.au/Api/ downloadmedia/\%7BF18A2239-E96F-4A49-98F1C9124E81163F\%7D. Accessed 8 Mar 2019.

35. Fischer DP, Zacharowski KD, Meybohm P. Savoring every drop-vampire or mosquito? Crit Care 2014;18:306.

36. Stefanini M. Iatrogenic anemia (can it be prevented?). J Thromb Haemost 2014;12:1591.

37. Ullman AJ, Keogh S, Coyer F, Long DA, New K, Rickard CM. 'True blood' the critical care story: an audit of blood sampling practice across three adult, paediatric and neonatal intensive care settings. Aust Crit Care 2016;29:905.

38. Squire Y, Laxton C. Blood conservation techniques. Tutorial 390. Available from: https://www.wfsahq.org/ components/com_virtual_library/media/8d6712e97e44cd 3c3c2af5cc1cbffc00-atow-390-00-01.pdf. Accessed 15 Nov 2019.

39. Jamnicki $M$, Kocian $R$, van der Linden $P$, Zaugg $M$, Spahn DR. Acute normovolemic hemodilution: physiology, limitations, and clinical use. J Cardiothoracic Vasc Anesth 2003;17:747-54.

40. Pasternak J, Nikolic D, Milosevic D, Popovic V, Markovic V. An analysis of the influence of intra-operative blood salvage and autologous transfusion on reducing the need for allogeneic transfusion in elective infrarenal abdominal aortic aneurysm repair. Blood Transfus 2014;12 Suppl 1:s182-6.

41. Ker K, Prieto-Merino D, Roberts I. Systematic review, metaanalysis and meta-regression of the effect of tranexamic acid on surgical blood loss. Br J Surg 2013;100:1271-9.

42. Alshryda S, Sukeik M, Sarda P, Blenkinsopp J, Haddad FS, Mason JM. A systematic review and meta-analysis of the topical administration of tranexamic acid in total hip and knee replacement. Bone Joint J 2014;96-B:1005-15.

43. Cheriyan T, Maier SP 2nd, Bianco K, et al. Efficacy of tranexamic acid on surgical bleeding in spine surgery: a meta-analysis. Spine J 2015;15:752-61.

44. National Blood Authority Australia. Patient Blood Management Guidelines: Module 2: Perioperative. Available from: https://www.blood.gov.au/pubs/pbm/ module2/3-clinical-guidance/3.6.5-acute-normovolemichaemodilution.html. Accessed 27 Apr 2020.

45. Murray D. Acute normovolemic hemodilution. Eur Spine J 2004;13 Suppl 1:S72-5.

46. Ko MT, Chuang KC, Su CY. Multiple analyses of factors related to intraoperative blood loss and the role of reverse Trendelenburg position in endoscopic sinus surgery. Laryngoscope 2008;118:1687-91.

47. Park CK. The effect of patient positioning on intraabdominal pressure and blood loss in spinal surgery. Anesth Analg 2000;91:552-7.

48. Franchini M, Mengoli C, Marietta $M$, et al. Safety of intravenous tranexamic acid in patients undergoing major orthopaedic surgery: a meta-analysis of randomised controlled trials. Blood Transfus 2018;16:36-43.

49. Houston BL, Uminski K, Mutter T, et al. Efficacy and safety of tranexamic acid in major non-cardiac surgeries at high risk for transfusion: a systematic review and meta-analysis. Transfus Med Rev 2020;34:51-62.

50. Shah A, Palmer AJ, Klein AA. Strategies to minimize intraoperative blood loss during major surgery. Br J Surg 2020;107:e26-38.

51. Albertin A, La Colla L, Gandolfi A, et al. Greater peripheral blood flow but less bleeding with propofol versus sevoflurane during spine surgery: a possible physiologic model? Spine (Phila Pa 1976) 2008;33:2017-22.

52. Boonmak P, Boonmak S, Laopaiboon M. Deliberate hypotension with propofol under anaesthesia for functional endoscopic sinus surgery (FESS). Cochrane Database Syst Rev 2016;10(10):CD006623.

53. Paul JE, Ling E, Lalonde C, Thabane L. Deliberate hypotension in orthopedic surgery reduces blood loss and transfusion requirements: a meta-analysis of randomized controlled trials. Can J Anaesth 2007;54:799-810.

54. Tran A, Yates J, Lau A, Lampron J, Matar M. Permissive hypotension versus conventional resuscitation strategies in adult trauma patients with hemorrhagic shock: A systematic review and meta-analysis of randomized controlled trials. J Trauma Acute Care Surg 2018;84:802-8.

55. Harper CM, Andrzejowski JC, Alexander R. NICE and warm. Br J Anaesth 2008;101:293-5.

56. Reynolds L, Beckmann J, Kurz A. Perioperative 
complications of hypothermia. Best Pract Res Clin Anaesthesiol 2008;22:645-57.

57. National Institute for Health and Care Excellence. Clinical guideline CG65. Hypothermia: prevention and management in adults having surgery. Available from: https://www.nice.org.uk/guidance/cg65. Accessed $20 \mathrm{Apr}$ 2020.

58. Segal JB, Blasco-Colmenares E, Norris EJ, Guallar E. Preoperative acute normovolemic hemodilution: a metaanalysis. Transfusion 2004;44:632-44.

59. Hedner U. Recombinant activated factor VII: 30 years of research and innovation. Blood Rev 2015;29 Suppl 1:S4-8.

60. Tinmouth AT, McIntyre LA, Fowler RA. Blood conservation strategies to reduce the need for red blood cell transfusion in critically ill patients. CMAJ 2008;178(1):49-57.

61. AuBuchon JP, Puca K, Saxena S, Shulman IA, Waters JH. Getting started in patient blood management. 2011. Available from: https://www.aabb.org/pbm/ Documents/112024DB.pdf. Accessed 8 Mar 2019.

62. Gleason E, Grossman S, Campbell C. Minimizing diagnostic blood loss in critically ill patients. Am J Crit Care 1992;1:85-90

63. European Directorate for the Quality of Medicines \& HealthCare. Guide to the preparation, use and quality assurance of blood components. Recommendation No. R (95) 15. Available from: http://www.ipst.pt/files/IPST/ INFORMACAO_DOCUMENTACAO/EDQM_Blood transfusion_guide_19ed_2017_pub_PUBSD-89.pdf. Accessed 8 Mar 2019.
64. Joint United Kingdom (UK) Blood Transfusion and Tissue Transplantation Services Professional Advisory Committee. Transfusion Handbook. 4: Safe transfusion-right blood, right patient, right time and right place. Available from: https://www.transfusionguidelines.org/transfusionhandbook/4-safe-transfusion-right-blood-right-patientright-time-and-right-place. Accessed 8 Mar 2019.

65. World Health Organization. Developing a national policy and guidelines on the clinical use of blood: recommendations. Available from: https://www.who.int/ bloodsafety/clinical_use/en/who_bct_bts_01_3.pdf?ua=1. Accessed 8 Mar 2019.

66. Mbanya D. Barriers and enablers to introducing comprehensive patient blood management in the hospital. Biologicals 2012;40:205-8.

67. Delaforce A, Duff J, Munday J, Hardy J. Overcoming barriers to evidence-based patient blood management: a restricted review. Implement Sci 2020;15:6.

68. European Commission. Building national programmes of patient blood management (PBM) in the EU-a guide for health authorities. Available from: https://ec.europa.eu/ health/sites/health/files/blood_tissues_organs/docs/2017 eupbm_authorities_en.pdf. Accessed 8 Mar 2019.

69. European Commission. Supporting Patient Blood Management (PBM) in the EU-A practical implementation guide for hospitals. Mar 2017. Available from: https:// ec.europa.eu/health/sites/health/files/blood_tissues organs/docs/2017_eupbm_hospitals_en.pdf. Accessed 8 Mar 2019. 